\title{
Diagnosing Moisture Sources for Flash Floods in the United States. Part I: Kinematic Trajectories $\mathscr{D}$
}

\author{
JESSICA M. ERLINGIS \\ Cooperative Institute for Mesoscale Meteorological Studies, and School of Meteorology, University of Oklahoma, \\ and NOAA/National Severe Storms Laboratory, Norman, Oklahoma \\ JONATHAN J. GOURLEY \\ NOAA/National Severe Storms Laboratory, and School of Meteorology, University of Oklahoma, Norman, Oklahoma
}

JEFFREY B. BASARA

School of Meteorology, and School of Civil Engineering and Environmental Science, University of Oklahoma, Norman, Oklahoma

(Manuscript received 6 June 2018, in final form 1 May 2019)

\begin{abstract}
This study uses backward trajectories derived from North American Regional Reanalysis data for 19253 flash flood reports during the period 2007-13 published by the National Weather Service to assess the origins of air parcels for flash floods in the conterminous United States. The preferred flow paths for parcels were evaluated seasonally and for six regions of interest: the West Coast, Arizona, the Front Range of the Rocky Mountains, Flash Flood Alley in south-central Texas, the Missouri Valley, and the Appalachians. Parcels were released from vertical columns in the atmosphere at times and locations where there were reported flash floods; these were traced backward in time for 5 days. The temporal and seasonal cycles of flood events in these regions are also explored. The results show the importance of trajectories residing for long periods over oceanic regions such as the Gulf of Mexico and the Caribbean Sea. The flow is generally unidirectional with height in the lower layers of the atmosphere. The trajectory paths from oceanic genesis regions to inland hotspots and their orientation with height provide clues that can assist in the diagnosis of impending flash floods. Part II of this manuscript details the land-atmosphere interactions along the trajectory paths.
\end{abstract}

\section{Introduction}

Flash floods are among the deadliest and costliest natural disasters that affect the United States and are especially difficult from a forecasting perspective as they involve predicting where, when, and how much rainfall will occur as well as the hydrological response to that rainfall. The number of people killed by floods is surpassed only by those killed by heat in the 30 -yr average from 1986 to 2015 (Ashley and Ashley 2008), and the frequency of heavy rainfall events, one causative factor

Supplemental information related to this paper is available at the Journals Online website: https://doi.org/10.1175/JHM-D-180119.s1.

\footnotetext{
Corresponding author: Jessica M. Erlingis, jessica.erlingislamers@ nasa.gov
}

for flash flooding, has been increasing (Karl and Knight 1998; Groisman et al. 2012). With intensification of precipitation extremes expected under a changing climate (e.g., Kharin et al. 2013; Wuebbles et al. 2014; Prein et al. 2017), it is therefore imperative that we improve our understanding of the physical processes associated with flash flooding, including critical source regions of water vapor and the impact of land-atmosphere interactions on flood-producing storms.

At the basin scale, Saharia et al. (2017) identified regions that are particularly susceptible to flash flooding from 78 years of USGS streamflow observations using a variable called "flashiness," $\phi_{i j}$, defined for a given stream gauge $i$ and a given event $j$ as

$$
\phi_{i j}=\frac{Q_{i j}^{(p)}-Q_{i j}^{(a)}}{A_{i} T_{i j}},
$$




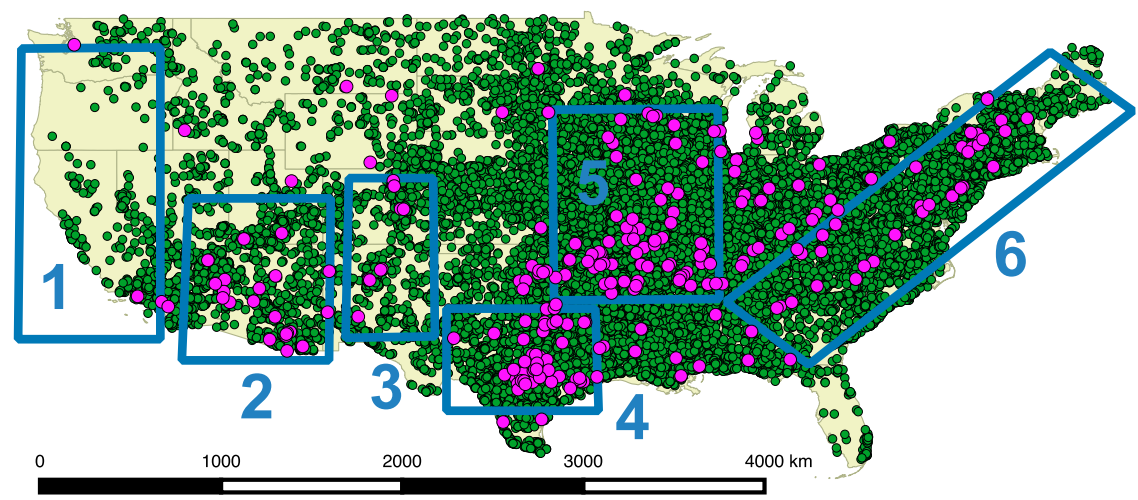

FIG. 1. Flash flood events from Storm Data (green) and direct fatality events (pink) with flashiness regions overlaid. The regions are defined as follows: 1) West Coast, 2) Arizona, 3) Front Range, 4) Flash Flood Alley, 5) Missouri Valley, and 6) Appalachians.

where $Q^{(p)}$ denotes peak (maximum) discharge, $Q^{(a)}$ denotes action stage discharge as defined by the National Weather Service (NWS), $A$ is the basin area, and $T$ is the flooding rise time (time between action stage discharge and peak discharge). The flashiness variable was then scaled based on the cumulative distribution function and summarized at the basin level by its median value. After deriving the flashiness across the conterminous United States, they identified the following regions as having anomalously high values of flashiness: the West Coast, Arizona, the Front Range of the Rocky Mountains, Flash Flood Alley in south-central Texas, the Missouri Valley, and the Appalachians. These regions are shown in Fig. 1, and the key drivers for precipitation and flooding in these regions will be described in the following section.

In the atmosphere, synoptic patterns conducive for heavy rainfall have been identified and classified in previous studies. These studies, however, often contain a limited number of cases or are limited to a specific geographical extent. Maddox et al. (1979) examined 151 flash flood cases from 1973 to 1977 and classified them according to four types based on surface weather patterns: synoptic, frontal, mesohigh, and western. They identified the common characteristics of flash flood events as follows: 1 ) association with convective storms, 2) high surface dewpoint temperatures, 3) relatively high moisture content throughout a deep tropospheric layer, 4) weak to moderate vertical wind shear, 5) training of convective storms, 6) a weak, midtropospheric meso- $\alpha$-scale trough to trigger and focus convection, 7) proximity to a midtropospheric largescale ridge, and 8) nocturnal storms. Doswell et al. (1996) presented an ingredients-based methodology for forecasting heavy rainfall with the potential to produce flash flooding, which included a conditionally unstable environmental lapse rate, sufficient moisture so that a level of free convection (LFC) exists, and a process to lift a parcel to its LFC. They also noted that storm motion plays an important role in flash flood producing storms, with long duration systems having one or both the qualities of slow storm movement or a large area of high rainfall rates along the storm motion vector.

Brooks and Stensrud (2000) developed a climatology of heavy rainfall $\left(\geq 25.4 \mathrm{~mm} \mathrm{~h}^{-1}\right)$ events for the conterminous United States (CONUS). The monthly distribution of heavy rainfall events for the CONUS is symmetric and peaks in July. Spatially, they found that heavy rainfall events are confined to the Gulf Coast region from October through March but extend into the areas east of the Rockies from April through September. Schumacher and Johnson (2006) examined 382 rainfall events of $125 \mathrm{~mm}(24 \mathrm{~h})^{-1}$ from 1999 to 2003 by region and applied a varying rainfall frequency threshold to several regions east of the Rockies. By analyzing radar data for the 184 events selected by a spatially varying rainfall frequency threshold $(90 \%$ of which had a corresponding flash flood report), they found that mesoscale convective systems (MCSs) are the most common producer of extreme rainfall in every region but the Southeast, where tropical cyclones or their remnants are the cause of the most extreme rainfall. Last, Hirschboeck (1991) outlines conceptual atmospheric moisture delivery pathways based on average surface winds and precipitable water.

Over the West Coast of the United States, heavy rainfall and flooding occur during the cool season, and are often associated with the atmospheric river (AR) phenomenon, a term coined by Zhu and Newell (1998) to describe long, narrow filaments of meridional water vapor transport, often with their origin in the tropics. These features account for $90 \%$ of poleward vapor transport (Ralph et al. 2004). Ralph et al. (2004) formalized the AR 
characterization to describe regions of integrated water vapor (IWV) of greater than $2 \mathrm{~cm}$ in a plume, with a length greater than $2000 \mathrm{~km}$ and a width of less than $1000 \mathrm{~km}$. Moisture transport occurs within the lowest $2.25 \mathrm{~km}$ of the atmosphere (Ralph et al. 2006). Using Special Sensor Microwave Imager (SSM/I) data, Neiman et al. (2008) showed that climatologically this phenomenon affects the southern portion of the West Coast most frequently during the winter and the northern portion of the West Coast most frequently during the summer, though both regions have their maximum rainfall totals in the cool season. During the winter, storms associated with this enhanced water vapor transport produce twice as much rain as other storms (Neiman et al. 2008) and are responsible for severe flooding. Flash flooding can occur with heavy rainfall when the plumes of high IWV impinge on both the Coastal Range and the Sierra Nevada mountains (Galewsky et al. 2005; Ralph et al. 2006; Smith et al. 2010).

The North American monsoon system (NAMS) impacts southwestern North America and is the primary driver for much of the warm season rainfall received in Arizona (Adams and Comrie 1997). The shift of the prevailing westerlies poleward begins the development phase of the NAMS in May-June, and a mid- to-upper tropospheric anticyclone develops over North America, reaching its mature phase from July to September (Maddox et al. 1995). The largest height increases over the Southwest are due to atmospheric heating over elevated terrain (Higgins et al. 1997), though the height increase during the NAMS is not as large as its South Asian counterpart. Sea surface temperatures (SSTs) of greater than $29.5^{\circ} \mathrm{C}$ across the Gulf of California are required to simulate the NAMS (Stensrud et al. 1995), and Mitchell et al. (2002) showed that $75 \%$ of rainfall in New Mexico and Arizona occurred with Gulf of California SSTs greater than $29^{\circ} \mathrm{C}$.

Some of the most infamous flash floods have occurred along the Front Range of the Rocky Mountains: the Big Thompson Canyon flash flood (Maddox et al. 1978; Caracena et al. 1979), the Fort Collins flash flood (Petersen et al. 1999; Ogden et al. 2000), and the Great Colorado Flood of 2013 (Gochis et al. 2015). In a study of more than 300 rainfall events, Petersen et al. (1999) described a bimodal distribution of heavy rainfall. One peak occurs from late May to early June associated with moderately intense synoptic-scale precipitation with embedded convection, and another peak occurs later in the summer from late July to early September associated with localized thunderstorms, often in the eastern foothills of the Rockies. The catastrophic flooding events noted above are infrequent and often are not highlighted in studies using a conventional peak-over-threshold analysis for flood events as in Smith and Smith (2015).

The region in central Texas, including the major cities of New Braunfels, San Antonio, Austin, Waco, and Dallas, is colloquially known as "Flash Flood Alley." This region's proximity to moisture-rich air from the Gulf of Mexico has resulted in favorable environments for extremes in precipitation. Along the Balcones Escarpment, a region of sloping terrain that separates the coastal plains from the Edwards Plateau (Texas Hill Country), there are several physiographic features that lead to enhanced runoff production: sparse vegetation, narrow valleys, and a shallow soil depth to limestone bedrock (Baker 1975; Caran and Baker 1986). It has also been proposed that the topography leads to a slight enhancement in precipitation (Nielsen et al. 2016). Additionally, the rapid urbanization has increased the impervious surface area in the region and more people are now at risk in a region prone to some of the deadliest flooding in the United States.

In the central United States, the seasonal maximum in rainfall occurs in May-June (Wang and Chen 2009). Carbone and Tuttle (2008) showed that propagating precipitation episodes that originate along the Continental Divide account for $60 \%$ or all June-August rainfall in the central United States. Self-sustaining organized convection, the mountain-plains circulation (ascending branch), and Great Plains low level jet (GPLLJ) contribute to a nocturnal maximum in precipitation. Mo et al. (1997) described enhancements in westerlies in the eastern Pacific and western North America from $30^{\circ}$ to $40^{\circ} \mathrm{N}$ for wet events in the central United States, with a strengthening and more northern extent of the GPLLJ. Schumacher and Johnson (2005, 2006) emphasized the importance of back-building and quasi-stationary MCSs to heavy rainfall in this region. Lavers and Villarini (2013) performed a hydrometeorological analysis of flood events from 1979 to 2011 and showed that $50 \%$ of their study basins' annual maximum floods were associated with high integrated vapor transport (IVT). Vapor transport often has origins further than the GPLLJ, and is associated with transport from the Caribbean as well, via the Caribbean LLJ (Cook and Vizy 2010). Sea surface salinity anomalies in the subtropical North Atlantic, indicating enhanced evaporation and vapor flux away from the region, significantly correlate with precipitation over the Midwest ( $\mathrm{Li}$ et al. 2016) This region has also been identified as a region where nonlocal soil moisture anomalies (DeAngelis et al. 2010; Kustu et al. 2011) and anomalous evaporative moisture in the Caribbean Sea (Dirmeyer and Kinter 2010) are correlated with heavy rainfall and flood events. 
TABLE 1. Number of flash flood events by region and by season. Direct fatality events are parenthesized.

\begin{tabular}{lccccc}
\hline \hline & DJF & MAM & JJA & SON & Total \\
\hline Region 1, West Coast & 31 & 11 & 68 & 50 & 160 \\
Region 2, Arizona & 40 & 7 & $753(13)$ & $227(3)$ & $1027(16)$ \\
Region 3, Front Range & 0 & 23 & $361(3)$ & $111(5)$ & $495(8)$ \\
Region 4, Flash Flood Alley & $67(2)$ & $666(18)$ & $652(9)$ & $359(10)$ & $1744(39)$ \\
Region 5, Missouri Valley & $242(3)$ & $1696(20)$ & $2629(16)$ & $594(4)$ & $5161(43)$ \\
Region 6, Appalachians & $267(1)$ & $799(1)$ & $2093(7)$ & $743(6)$ & $3902(15)$ \\
\hline
\end{tabular}

Along the Appalachian Mountains, there is a seasonal maximum of thunderstorms in mid-July. A local minimum in lightning activity (a proxy for convective activity) occurs over the highest terrain in the Appalachians but local maxima occur on both the western and eastern slopes (Smith et al. 2011). Smith et al. (2011) also noted that some of the most historic peaks in discharge values occurred with terrain-locked thunderstorms. Orographic enhancement of precipitation (Hicks et al. 2005) is also a factor when considering flood producing storms in the region. This region is also unique in the role that tropical cyclones play in its water budget. The stretch along the Appalachians from North Carolina to Vermont boasts the highest ratio of tropical cyclone events to flood peaks (Villarini et al. 2014), and tropical cyclones have the largest effect on the tails of flood peak distributions (Villarini and Smith 2010). Tropical cyclones impinging on the Appalachian Mountains have produced hazards such as flooding and landslides during Fran (Sturdevant-Rees et al. 2001), Fay (Tao and Barros 2013), Frances, and Ivan (Wooten et al. 2008), among others.

The first part of this study presents the seasonal and regional variability of flash floods in the six regions described above. The companion paper addresses the impact of land-atmosphere interactions on the moisture budgets of transient air parcels. The large sample size presented in these combined papers reflects a wide array of hydrometeorological conditions that drive flash flooding throughout the contiguous United States. While it does not encompass every possible scenario that could generate flash flooding, the number of cases considered here can both confirm and build upon the results from the bodies of work discussed in this section.

This paper is organized as follows: section 2 describes the datasets and methodology used for this study, and section 3 describes the seasonal and temporal distributions of flash floods in these regions as well as the predominant flow paths at several levels in the lower atmosphere. Section 4 provides a synthesis of the first part of the manuscript and introduces the content of the companion paper.

\section{Methodology}

This study uses the wind fields in North American Regional Reanalysis (NARR; NCEP 2005; Mesinger et al. 2006) data to calculate kinematic backward trajectories for a database of flash flood events in order to assess the geographic origins of parcels that contribute to flash flooding in the CONUS. These events are then subdivided into six regions for further analysis. In the companion paper to this manuscript (Erlingis et al. 2019, hereafter Part II), an offline (uncoupled) run of a land surface model with finer grid spacing is used to investigate the land surface energy and water budgets along each parcel's trajectory.

Because there are multiple sources of flash flood information spread across agencies in the United States, Gourley et al. (2013) developed a unified flash flood database, which includes reports from NWS Storm Data, USGS records based on observed streamflow that exceed the NWS defined action stage for the gauges with defined flood stages, and reports solicited from the public during the Severe Hazards Analysis and Verification Experiment (SHAVE; Gourley et al. 2010) during the summers of 2008-10. The Storm Data flash flood reports from the 2007-13 archive (NSSL 2013) were used in this study because of the change in the reporting process that went into effect in 2007. After October 2007, the NWS began recording flash flooding events as bounding polygons of affected areas, while previously, reports had been recorded by county.

In total, 19253 flash flood events from NWS Storm Data within the CONUS were analyzed. Figure 1 shows both the spatial locations of the flash flood events and the flashiness regions delineated by Saharia et al. (2017). There is no operational measure of flash flood severity, though Schroeder et al. (2016) established the groundwork for a classification scale of flash flood events based on impacts. From the sample of reports, 231 contained at least one fatality in Storm Data. A summary of events by region and season is shown in Table 1. Flash flood reports in Storm Data contain a unique identifier for the report, the start and end time of the flood, the county, the number of direct and indirect injuries and fatalities, 


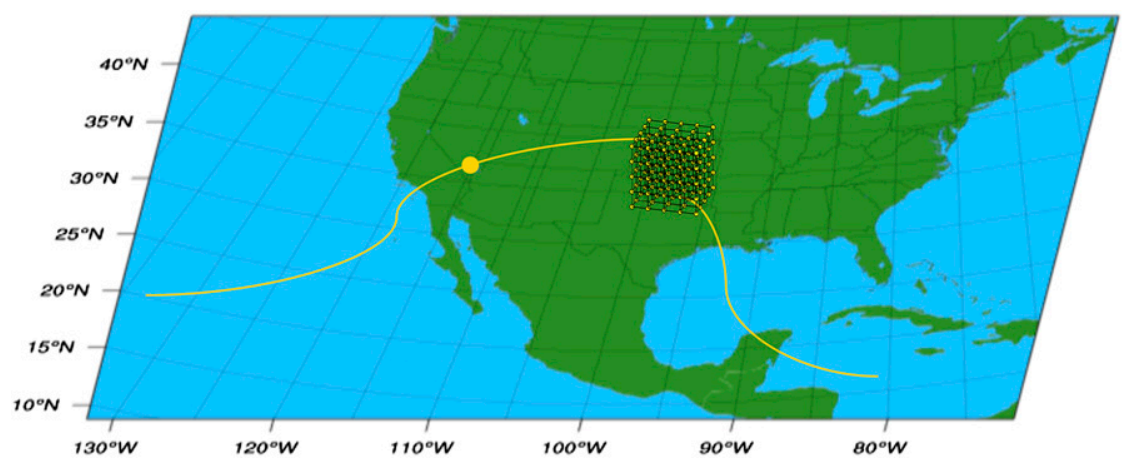

FIG. 2. Schematic showing the grid of particles initialized over a flash flood report with sample backward trajectories.

financial estimates of property and crop damage, the flood cause, the source of the report, and a brief narrative, along with up to eight latitude-longitude points defining a polygon of the affected area.

Reanalysis data were used instead of model forecasts for individual events because of the challenge in producing a multiday forecast with accuracy in terms of the spatial location, magnitude, and timing of rainfall (Wernli et al. 2008; Roberts et al. 2009; Vincendon et al.
2011; Hardy et al. 2016). These accuracies are essential when assessing the local and nonlocal impacts of the land surface. NARR data were used and are available at 3 -hourly intervals at $32-\mathrm{km}$ horizontal grid spacing. The study domain for calculating the trajectories and running the land surface model in Part II is a subset of the NARR domain: $1126 \times 699$ pixels with $6-\mathrm{km}$ horizontal grid spacing, chosen based on computational constraints.
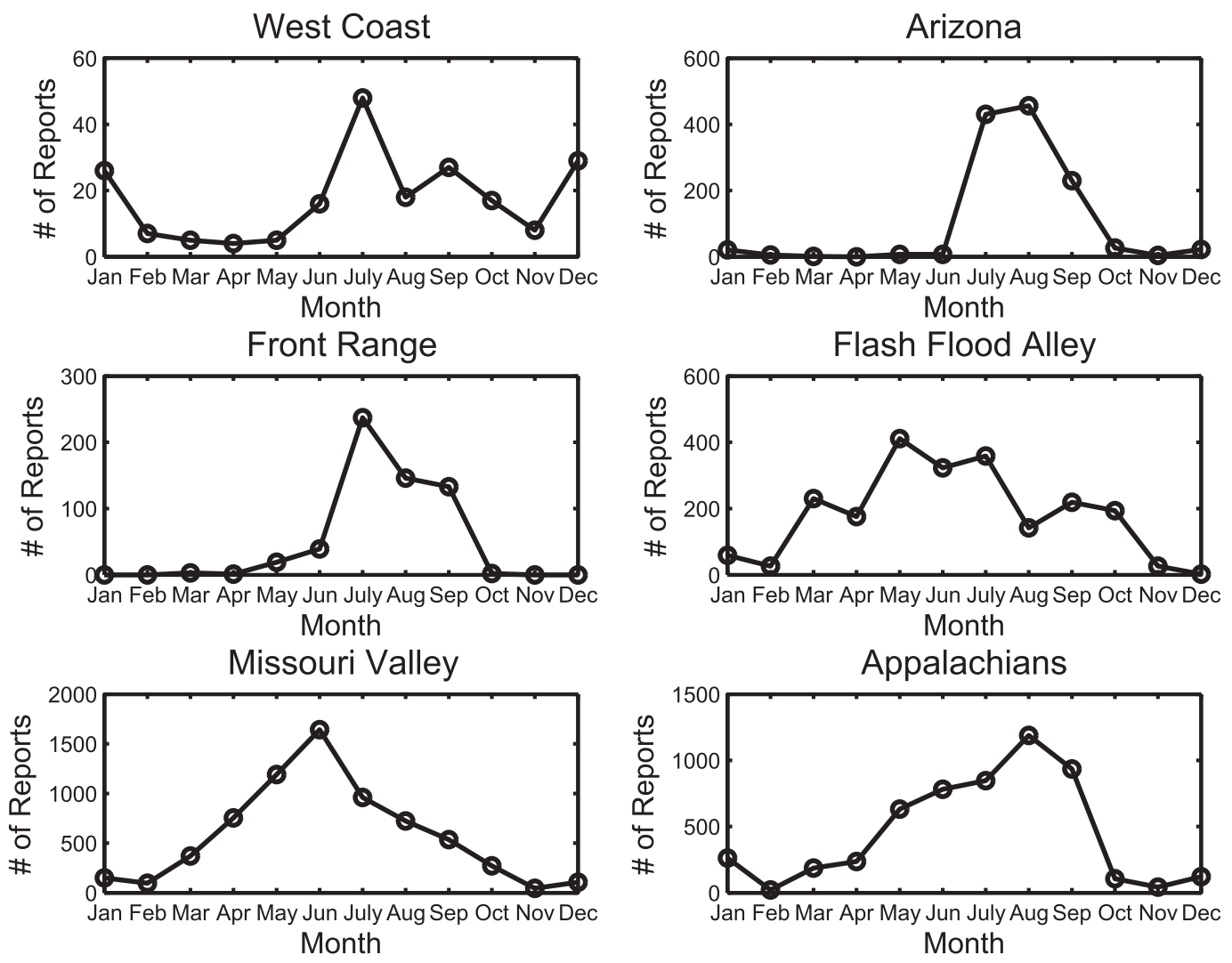

FIG. 3. Distribution of Storm Data flash flood reports by month for the region indicated. The scale varies in each subplot based on the number of reports in the region. 

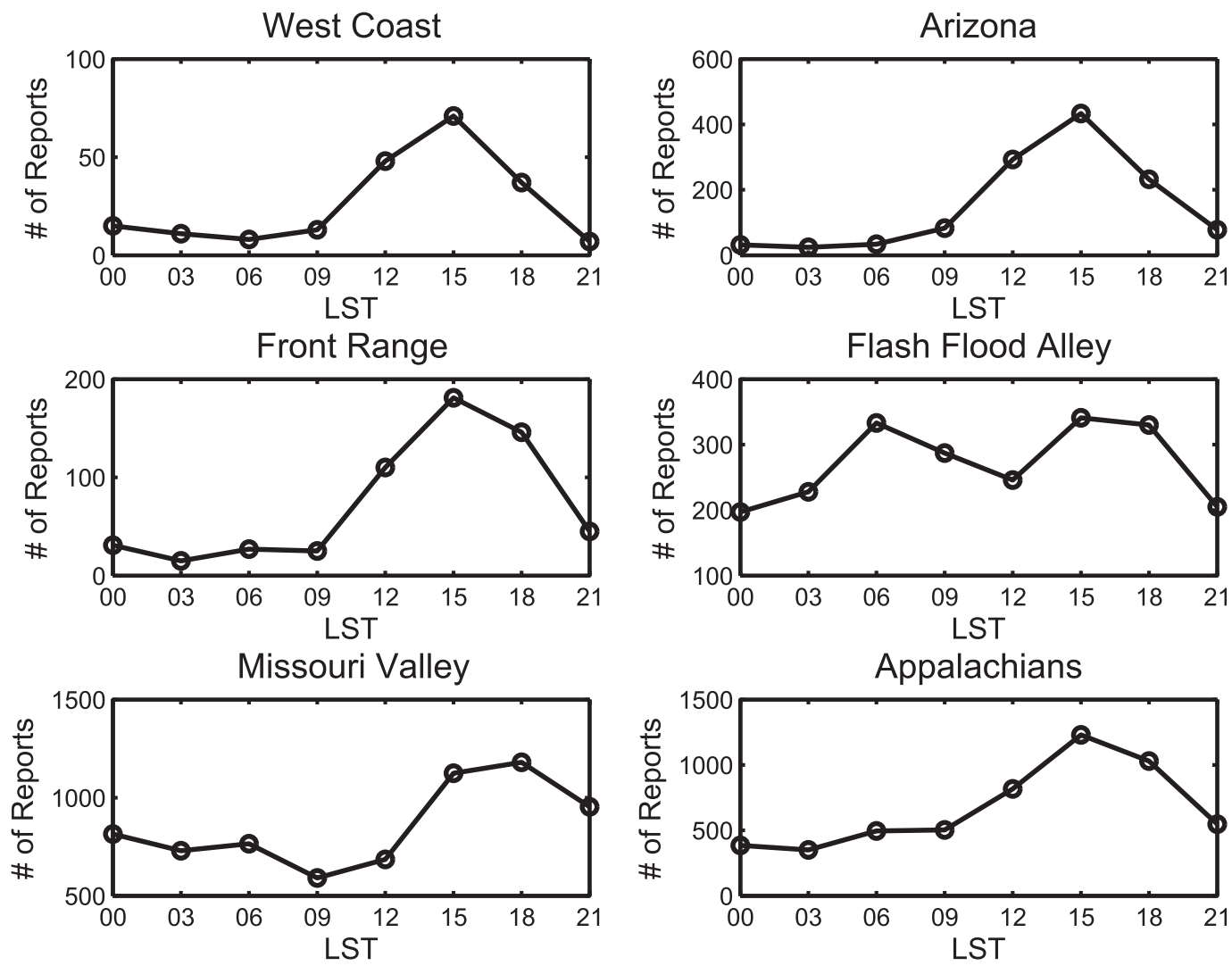

FIG. 4. Distribution of Storm Data floods by local standard time for each region (LST $=$ UTC -8 for Regions 1 and 2; LST $=\mathrm{UTC}-7$ for Region 3; LST $=\mathrm{UTC}-6$ for Regions 4 and 5, and LST $=\mathrm{UTC}-5$ for Region 6 ). Totals are reported at the beginning of each 3-h window (i.e., floods occurring between 0300 and 0600 UTC are marked at the 0300 UTC point). The scale varies in each subplot based on the number of reports in the region.

For each event, in order to account for spatial uncertainty in the trajectory calculations, a box of $11 \times 11$ grid cells was generated with the centroid of the flash flood report at the center of the grid. Parcel tracing began at the nearest 3-h time step prior to the flood start time. Parcels were spaced every $30 \mathrm{hPa}$ in the vertical from 950 to $470 \mathrm{hPa}$, and backward trajectories were computed for $120 \mathrm{~h}$ with an integration time step of $30 \mathrm{~min}$. The aforementioned spacing was chosen so as to concentrate parcels in the lower levels of the atmosphere where the bulk of the atmospheric moisture content resides. The temporal time scale was chosen to be a synoptic time scale, in between estimates for parcel backward trajectories at the time scale leading to convective events (Jana et al. 2018) and the total residence time for atmospheric water vapor in the atmosphere (Wang et al. 2018). This time scale was also chosen to keep parcels within the NARR domain. The parcel positions were recorded every $3 \mathrm{~h}$. A map of the domain and schematic of the setup for each event is shown in Fig. 2. Trajectory calculations were performed using the
Read/Interpolate/Plot (RIP; Stoelinga 2009) software program developed at National Center for Atmospheric Research (NCAR) and the University of Washington; RIP trajectories have recently been used for a variety of applications (e.g., Beck and Weiss 2013; Smart and Browning 2014; Tilev-Tanriover and Kahraman 2015; Slater et al. 2015; Hardy et al. 2017). Although the atmospheric forcing data were only available at 3-h intervals, linear interpolation of the velocity data was performed, and parcel positions were computed every $30 \mathrm{~min}$ to improve accuracy, as recommended by the developers.

\section{Results}

\section{a. Seasonal and temporal distribution of flood reports}

The Storm Data flash flood reports were first examined for seasonality and diurnal cycle by region. Figure 3 shows the distribution of events by season for each region. Many of the regions have a distinct monthly climatological maximum for flash floods. The West Coast of the United States (Region 1) has the maximum 


\section{Region 1 DJF}

$950 \mathrm{hPa}$

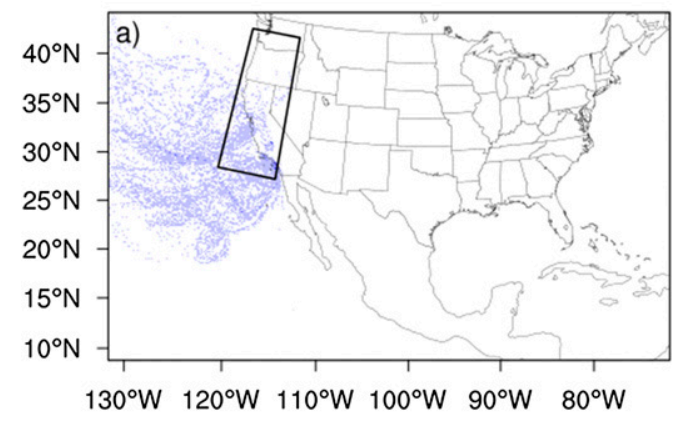

$700 \mathrm{hPa}$

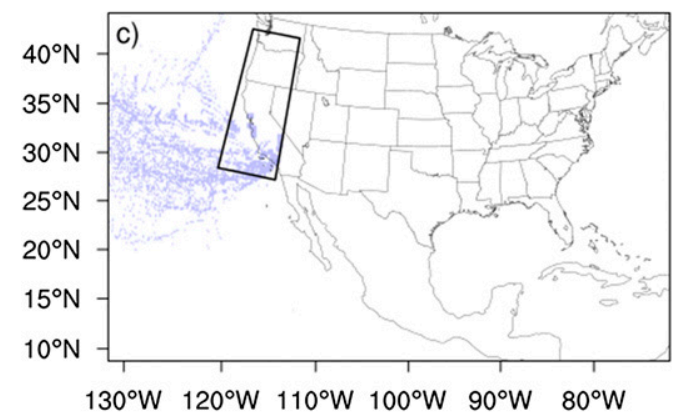

$850 \mathrm{hPa}$

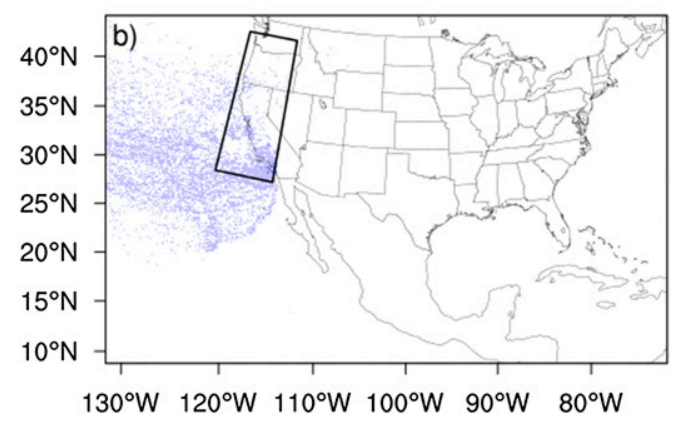

$500 \mathrm{hPa}$

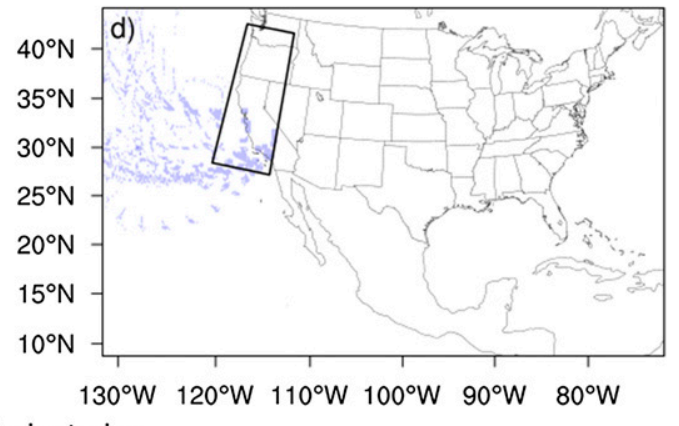

Number of Trajectories

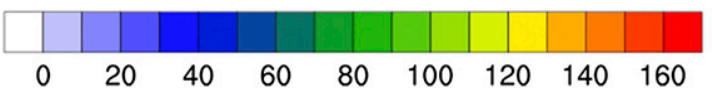

FIG. 5. Trajectory density (number of trajectories passing through a given grid point) for parcels ending at the approximate pressure level indicated for flash floods occurring in Region 1 (West Coast; outlined) during DJF.

number of flood events in July with secondary peaks in December and January. The summer and fall events for the West Coast occur in the eastern and southeastern portions of the domain as an extension of the NAMS. [While the bounding box for this region is the same as in Saharia et al. (2017), they include primarily events in the western portion of this subdomain, and this accounts for the difference in observed seasonality of floods. Results obtained in other regions are in general agreement with their results.] The maximum number of floods occurs in August in Arizona (Region 2) during the NAMS. Along the Front Range (Region 3), the maximum number of floods occurs from July to September. In Flash Flood Alley (Region 4), events are most likely to occur in May-July, but there is a secondary peak in the early fall, while in the Missouri Valley (Region 5), the number of floods increase until they peak in June and decrease thereafter. Last, along the spine of the Appalachians (Region 6), the number of floods increases until a maximum is reached in August with the fewest floods occurring in the late fall and winter. The seasonality of
Storm Data observations of flash flooding agrees well with the climatologies of heavy rainfall in these regions described in section 1 .

In Fig. 4, the distribution of Storm Data floods is shown for each region as a function of local time in order to assess the diurnal cycle of flash flooding in each region. For the West Coast, Arizona, and the Front Range there is a peak in floods occurring during the late afternoon, between 1500 and 1800 LST due to afternoon convection. For Flash Flood Alley, there is a similar afternoon peak due to daytime convection, but the distribution is bimodal with a maximum nearly equal in magnitude occurring between 0600 and 0900 LST, illustrative of the nocturnal maximum of convection as MCSs propagate from the Rockies. In the Missouri Valley, most floods occur between 1500 and 0000 LST, but there are also some floods occurring in the early morning hours, with a minimum from 0900 until 1200 LST, again due to the well-documented cycle of convection in the central United States. The Appalachians also have a maximum in the late afternoon hours. 


\section{Region 2 JJA}

$950 \mathrm{hPa}$

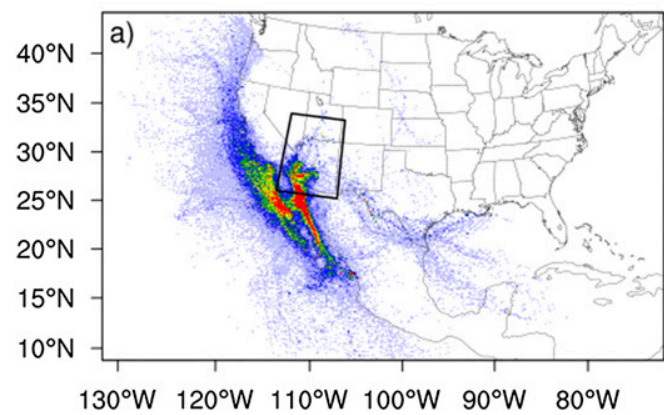

$700 \mathrm{hPa}$

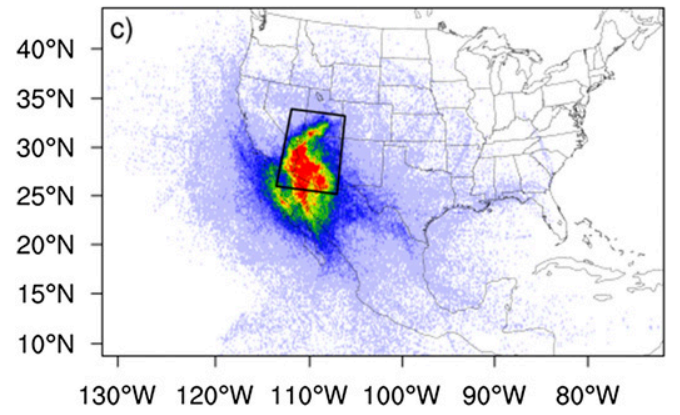

$850 \mathrm{hPa}$

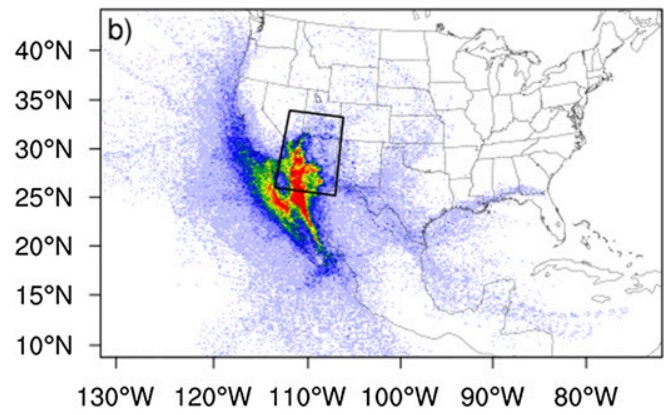

$500 \mathrm{hPa}$

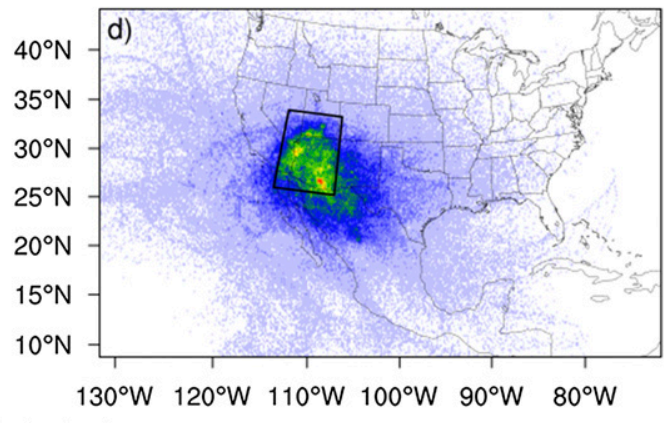

Number of Trajectories

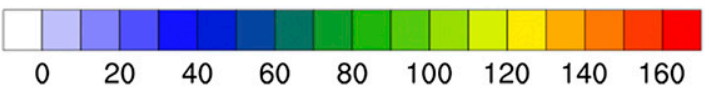

FIG. 6. As in Fig. 5, but for Region 2 (Arizona) during JJA.

\section{b. Parcel trajectory analysis}

Although parcels were spaced every $30 \mathrm{hPa}$ in the vertical from 950 to $470 \mathrm{hPa}$ (where much of the moisture in the troposphere resides) for the trajectory calculations, the following analyses focus on the parcel nearest to the mandatory synoptic levels $(950,850,700$, and $500 \mathrm{hPa}$ ) at the endpoint of the trajectory (parcels launched from 950, 860, 710, and $500 \mathrm{hPa}$ ). Values for selected atmospheric and land surface variables were recorded every $3 \mathrm{~h}$ along the trajectory. When separated by region and season, the trajectory analysis confirms that many of the well-documented regional climatological features are present and instrumental for flash flood events. The analysis presented in this section will focus on the seasons of peak flooding for each region, while the other seasons are included in the online supplemental material.

The following analyses consider the density of trajectories passing through a given grid point. All regions and seasons can be found in the supplemental material included with this manuscript. For the West Coast, during DJF there is nearly unidirectional flow at all levels off the Pacific Ocean (Fig. 5), indicative of extratropical cyclones and the moisture transport associated with enhanced vapor transport from the tropical Pacific, discussed extensively in section 1. In the spring, there are only 11 events, all of which have their flow at all levels from the Pacific Ocean. Because Region 1 as delineated by Saharia et al. (2017) includes portions of southern California and Nevada, there is a warm season peak in activity during the North American monsoon.

For Arizona, during DJF (Fig. S4), the flow resembles that of the West Coast region for the same season, with all trajectories originating over the Pacific Ocean. As it was for the West Coast, Region 2 has a minimum in flash flood reports during MAM, with only seven reports occurring during the study period. As the North American monsoon begins to develop and mature later in JJA (Fig. 6), the maximum concentration in parcel trajectories lower than $700 \mathrm{hPa}$ occurs off the coast of Baja California on the Pacific side and over the Gulf of California itself. Flow at $500 \mathrm{hPa}$ is curved around the anticyclone that forms in the midtroposphere during JJA and persists through the summer before tapering off 


\section{Region 3 JJA}

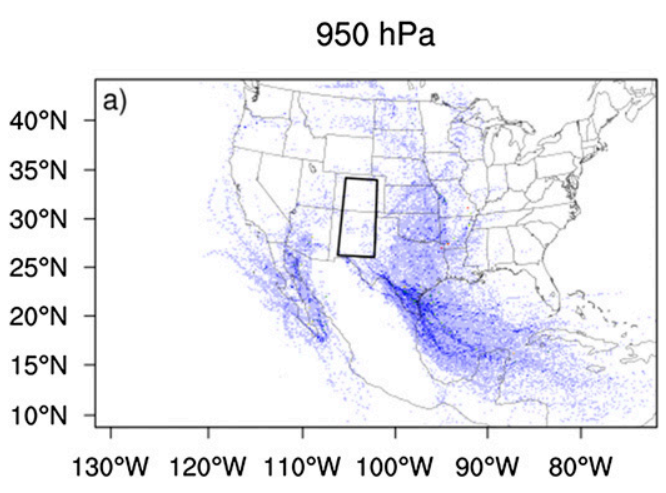

$700 \mathrm{hPa}$

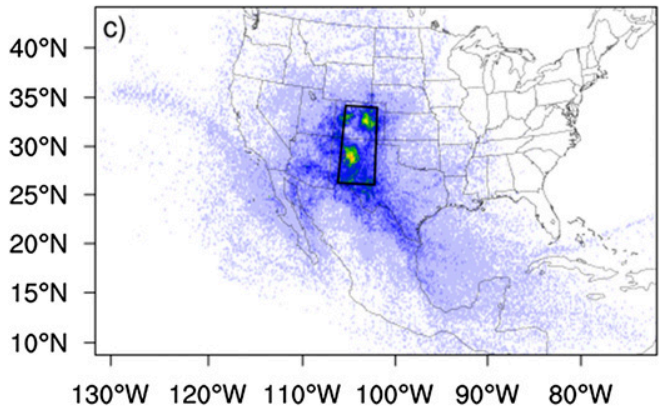

$850 \mathrm{hPa}$

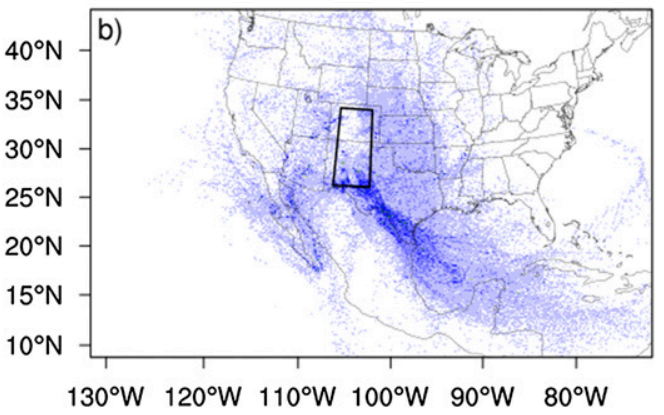

$500 \mathrm{hPa}$

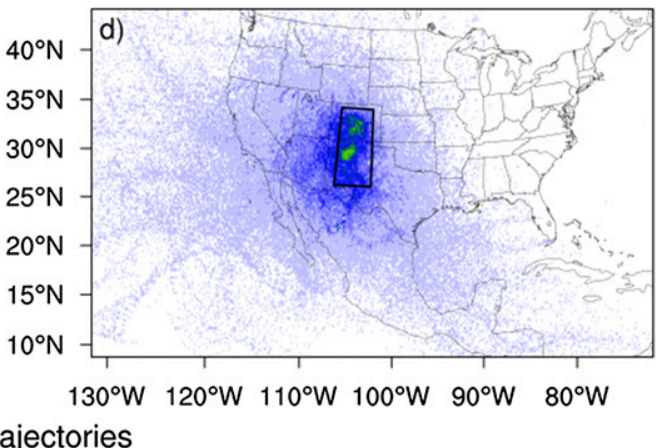

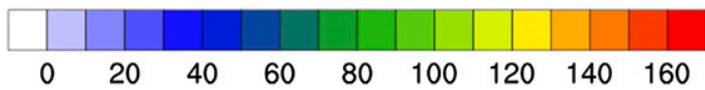

FIG. 7. As in Fig. 5, but for Region 3 (Front Range) during JJA.

during SON. These results are in agreement with Dominguez et al. (2016), who noted that lower level moisture comes primarily from the Gulf of California while local recycling and the Gulf of Mexico are secondary sources.

No floods occur during the study period during DJF in the Front Range (Region 3). For floods occurring along the Front Range in all other seasons, parcels ending at $850 \mathrm{hPa}$ have a long residence time over the Gulf of Mexico. Some parcels ending at $700 \mathrm{hPa}$ originate over the Gulf of Mexico and ascend as they reach the Front Range while some originate over the Pacific. Parcels ending at $500 \mathrm{hPa}$ exhibit a pattern similar to those in Arizona for JJA, indicative of some monsoonal effects over the southwestern United States (Fig. 7). Trajectories ending at $700 \mathrm{hPa}$ vary in origin from the Gulf of Mexico or Caribbean Sea, the Gulf of California and the Pacific Ocean, or from the north. For floods occurring in SON (Fig. S8), flow ending at 850 and $700 \mathrm{hPa}$ has two predominant flow paths: a primary fetch over the Gulf of Mexico and through western Texas and a secondary one that originates over the Gulf of California. The 500-hPa flow is westerly, however, save for a small fraction of parcels that ascend from over the Gulf of Mexico.

For Flash Flood Alley (Region 4), flow for DJF events exhibits a sharp northward turn for parcels ending at 950 and $850 \mathrm{hPa}$ through the Gulf of Mexico and into central Texas (Fig. S9) Flow for parcels ending at $700 \mathrm{hPa}$ descends from over central Mexico or over the western Gulf of Mexico. Flow for parcels ending at $500 \mathrm{hPa}$ is westerly or southwesterly, in association with a trough feature in the midtroposphere. For floods occurring in MAM (Fig. S10), the preferred flow path of parcels veers with height, though flow in the lower troposphere traverses the Gulf of Mexico. Flow for parcels ending at $950 \mathrm{hPa}$ is easterly to southeasterly off the northern Gulf of Mexico. For parcels ending at $850 \mathrm{hPa}$, it becomes southeasterly to southerly. For parcels ending at $700 \mathrm{hPa}$, the flow is southerly, and for parcels ending at $500 \mathrm{hPa}$, flow is predominantly southwesterly. In JJA (Fig. 8), the trajectories for parcels ending at $950 \mathrm{hPa}$ have a more southerly component than they do in the spring, and the area with the core of highest concentration of trajectories spans from the Caribbean Sea into 


\section{Region 4 JJA}

$950 \mathrm{hPa}$

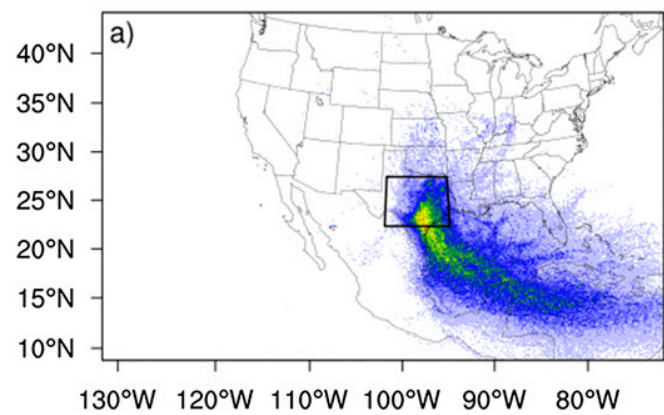

$700 \mathrm{hPa}$

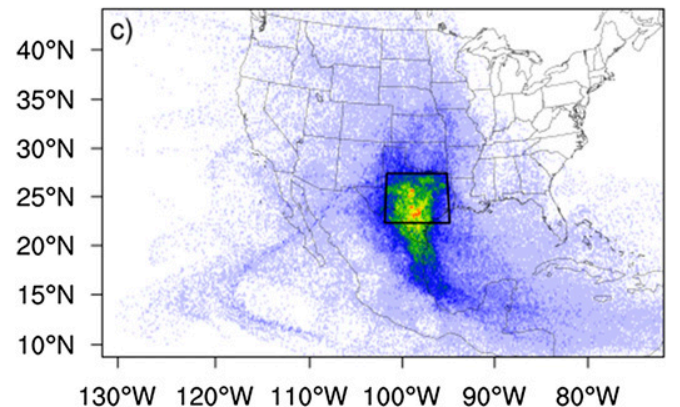

Number of Trajectories

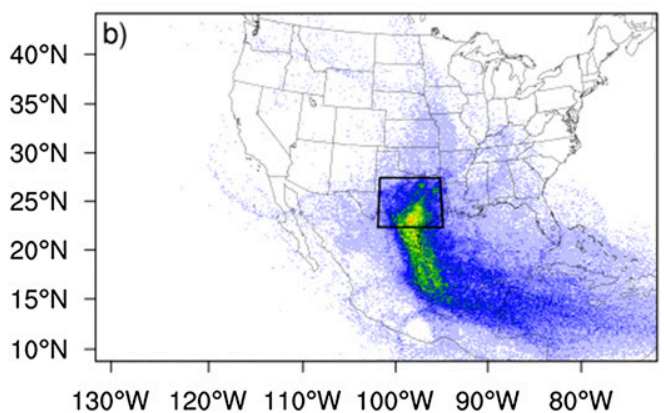

$500 \mathrm{hPa}$

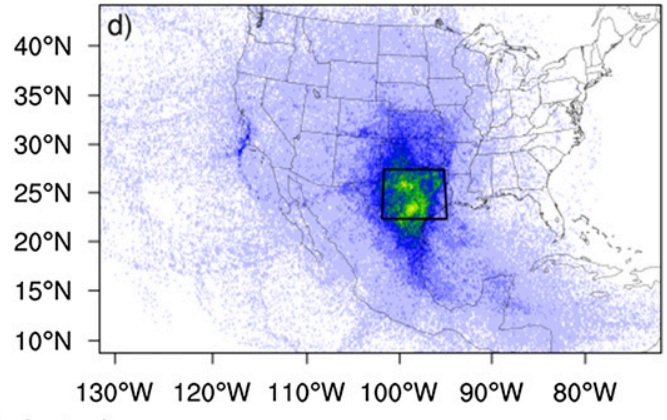

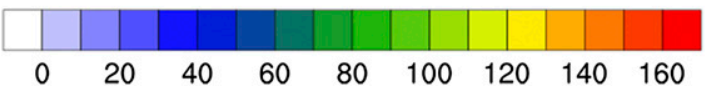

FIG. 8. As in Fig. 5, but for Region 4 (Flash Flood Alley) during JJA.

the Western Gulf of Mexico. Trajectories ending at 700 and $850 \mathrm{hPa}$ share a similar north-south-oriented axis. Some upper-level trajectories ascend from low levels over the Gulf of Mexico, while others exhibit cyclonic curvature from the southwest or anticyclonic curvature from the northwest. In SON, the lowest-level trajectories back slightly from their positions in JJA, and the 500-hPa flow becomes southwesterly again.

For the Missouri Valley (Region 5), the flow pattern of trajectories strongly resembles that of Flash Flood Alley. In DJF (Fig. S12), trajectories ending at $950 \mathrm{hPa}$ exhibit easterly flow across the northern Gulf of Mexico and curve to a southerly flow into the Missouri Valley. For trajectories ending at $850 \mathrm{hPa}$, this pattern is displaced southward, and parcels turn northward near the Mexican coast. Some trajectories that end at $700 \mathrm{hPa}$ exhibit the same pattern as those ending at $850 \mathrm{hPa}$, while others begin over the Pacific Ocean and descend. Flow for $500 \mathrm{hPa}$ is southwesterly. The two seasons with the most flash flood events are MAM and JJA in Region 5. The pattern of trajectory density during MAM bears similarity to that in DJF, except for a northward shift in the $500-\mathrm{hPa}$ trajectories. In JJA (Fig. 9), trajectories at $500 \mathrm{hPa}$ shift northward further, and are more variable over the Pacific Ocean than in the cool season. Trajectories that were launched from 950 and $850 \mathrm{hPa}$ track over the Caribbean Sea and Gulf of Mexico before turning northward and tracking across eastern Texas and Oklahoma, and over Arkansas and Missouri. Trajectories that end at $700 \mathrm{hPa}$ have a slightly more westerly component than those at lower levels. In the fall, the trajectories make a similar easterly shift from JJA to SON.

For the Appalachians (Region 6), identifying patterns is not as straightforward since the region spans a large area from north to south. The flow for parcels that terminate at 950 and $850 \mathrm{hPa}$ is highly curved and passes over the Atlantic Ocean in DJF. Many parcels ending at $700 \mathrm{hPa}$ pass over the Gulf of Mexico and along the Appalachians before reaching their final destinations. While some parcels launched from $500 \mathrm{hPa}$ have their origins in the Pacific Ocean, others begin in the Gulf of Mexico and Caribbean Sea and ascend as they move northward (Fig. S15). In MAM (Fig. S16), many lowlevel trajectories still approach from over the Atlantic. 


\section{Region 5 JJA}

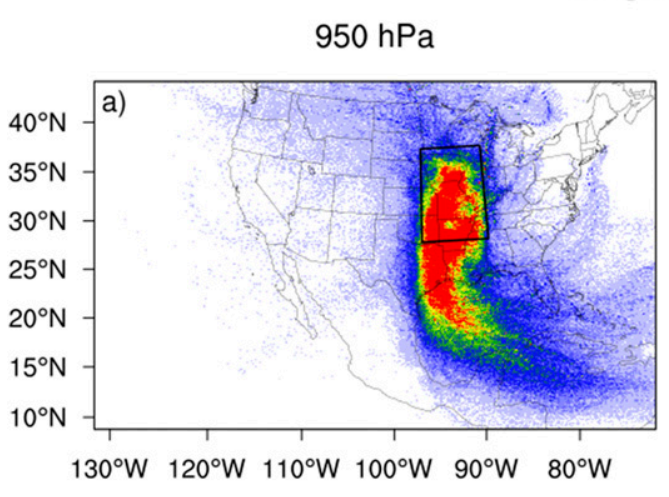

$700 \mathrm{hPa}$

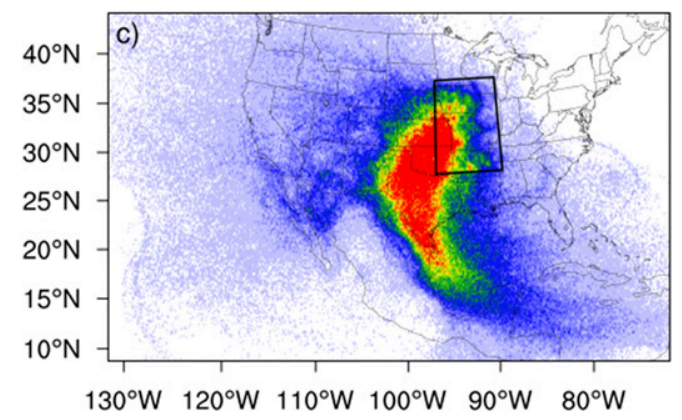

$850 \mathrm{hPa}$

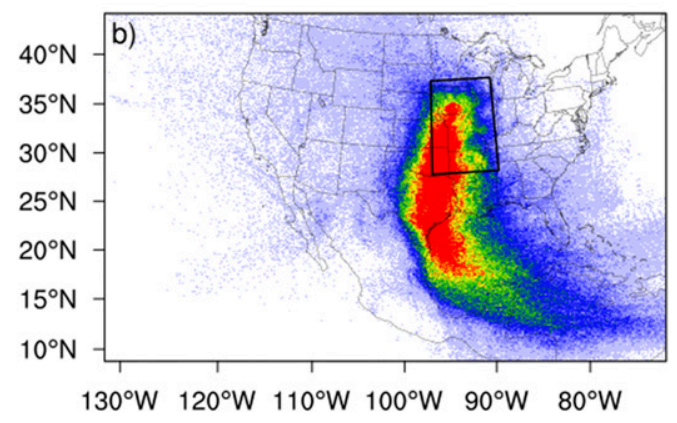

$500 \mathrm{hPa}$

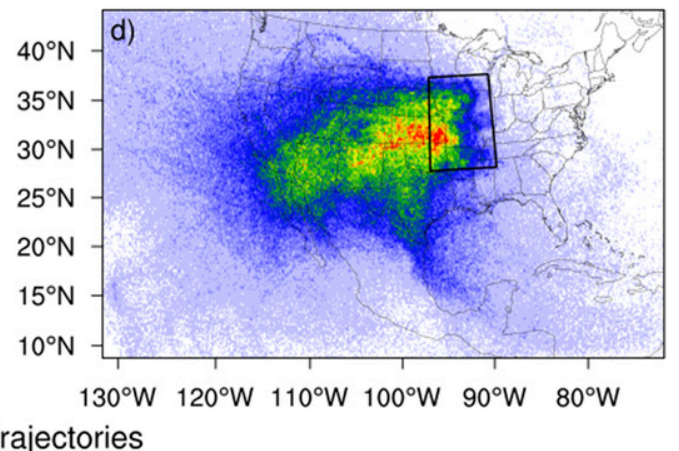

Number of Trajectories

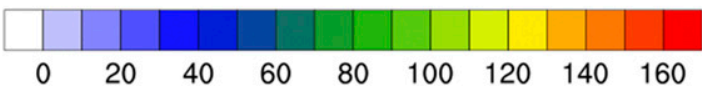

FIG. 9. As in Fig. 5, but for Region 5 (Missouri Valley) during JJA.

In JJA the maximum in parcel trajectory positions is located along the axis of the mountains, with some lowlevel flow off the Atlantic and Gulf of Mexico. In SON (Fig. 10), the parcels that terminate at 850 and $700 \mathrm{hPa}$ have their origins over the Gulf of Mexico or the Atlantic Ocean, while many of the parcels that terminate at $950 \mathrm{hPa}$ have their origins over the Atlantic Ocean.

\section{Summary and conclusions}

A total of 19253 flash flood reports from NWS Storm Data during the period 2007-13 were used to initialize backward trajectories to study source regions for flash flood events. Parcels were distributed horizontally in $66 \mathrm{~km} \times 66 \mathrm{~km}$ grids with $30-\mathrm{hPa}$ spacing in the vertical (from 950 to $470 \mathrm{hPa}$ ). The parcels were launched from these three-dimensional boxes, centered on the flash flood report, and traced backward $120 \mathrm{~h}$ (5 days) in order to assess the dominant track of parcels that terminate at various pressure levels in flash flooding setups. The analysis was divided into six regions of interest: 1 ) West Coast, 2) Arizona, 3) Front Range, 4) Flash Flood Alley,
5) Missouri Valley, and 6) Appalachians according to the flashiness regions delineated by Saharia et al. (2017). Cases were subdivided further by season (DJF, MAM, JJA, and SON) in order to study the seasonality of flash flood mechanisms. This methodology confirms many well-known mechanisms as key components for heavy rainfall in these regions and casts the results in a climatological context through the use of a very large dataset. The focus of the study on mandatory levels in the atmosphere provides a basis for identification of patterns that may lead to flash flooding by operational forecasters.

Primarily, flash flood events are a spring and summer phenomenon for the Front Range in Colorado, Flash Flood Alley, the Missouri Valley, and the Appalachians. Due to the summer NAMS activity, flash flooding in Arizona peaks in the late summer and early fall. The only region with significant wintertime flooding is the West Coast of the United States, associated with the atmospheric river phenomenon. Flash floods occur generally in the afternoon hours, associated with a peak in convective activity in these regions. In Flash Flood 


\section{Region 6 SON}

$950 \mathrm{hPa}$

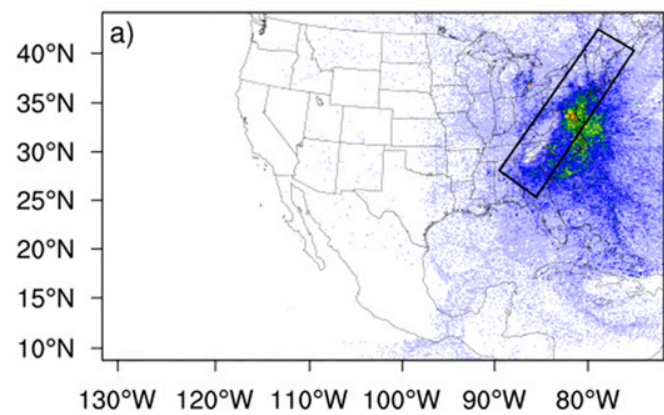

$700 \mathrm{hPa}$

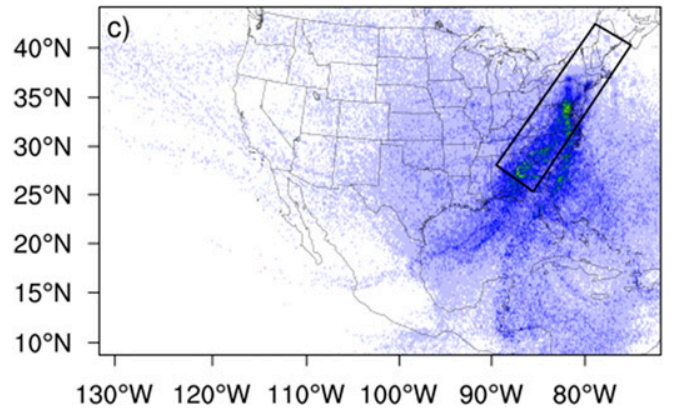

Number of Trajectories

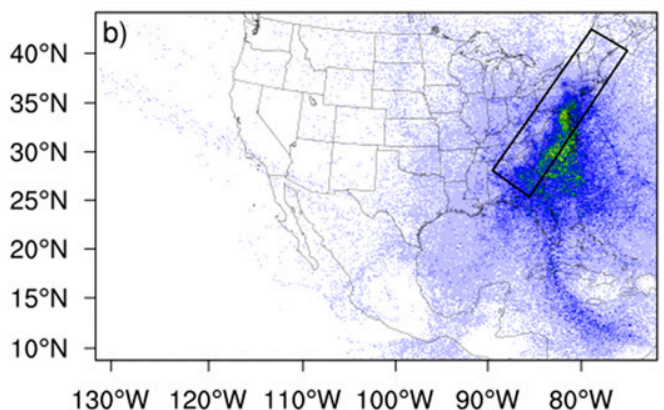

$500 \mathrm{hPa}$

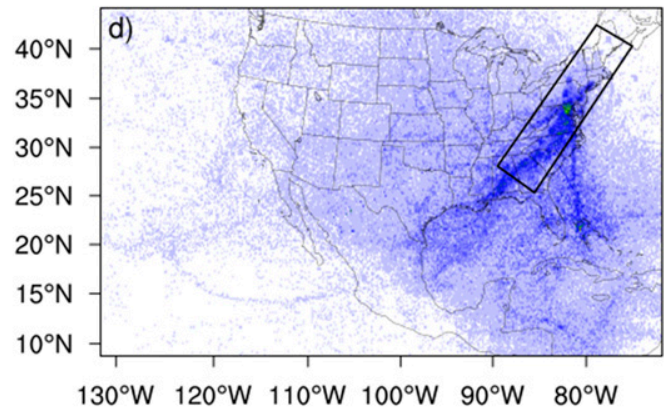

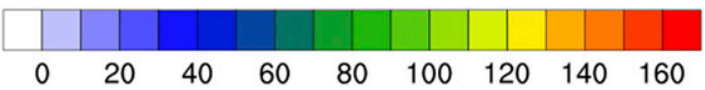

FIG. 10. As in Fig. 5, but for Region 6 (Appalachians) during SON.

Alley and to a lesser extent in the Missouri Valley, however, there is a secondary maximum in the early morning associated with the well-documented propagation of nocturnal convection in the central United States.

Five out of six of the studied regions share the common characteristics of 1) low-level parcels associated with flash flooding events originating from an oceanic source 2) impinging on a topographic feature, which induces orographic and isentropic ascent. Trajectory density plots reveal that the flow for flash flood events was unidirectional or slightly veering with height throughout the lower part of the troposphere. This is especially evident when, during DJF, the majority of final parcel moisture for the West Coast (Region 1) is attributable to advection and trajectories at all levels progress across the Pacific Ocean to their final destinations. For Region 2 (Arizona), low-level flow passes over the Gulf of California during the NAMS period in JJA and SON, confirming the moisture source for monsoon thunderstorms in this local region and beyond. For Region 3 (Front Range), there are two genesis regions for low-level parcels that transport moisture: the primary source is the Gulf of Mexico during the warm season where parcels traverse all of Texas to the Rocky Mountains in New Mexico and then travel northward. There is a secondary oceanic source region in the Gulf of California with low-level parcels traveling through south-central and southeast Arizona to New Mexico and then northward. In Flash Flood Alley (Region 4), the main moisture source is the Gulf of Mexico. In DJF, the low-level trajectories have a more westward component but become progressively more southerly from MAM to JJA. In the Missouri Valley (Region 5), many of the same patterns exist as in Region 4, with respect to parcel flow direction with height. In the Appalachians (Region 6), low-level parcels originate over either the Gulf of Mexico or the Atlantic Ocean and move parallel to the mountains, but future work will separate these into two separate regions (north and south) to investigate these patterns further.

While the climatology of heavy rainfall and thunderstorm events has been thoroughly studied using rain gauge observations, remote sensing, and model reanalyses, this work views the flash flood problem through a 
complementary Lagrangian lens, focusing on nonlocal precursors to these events. While forecasters may recognize a favorable synoptic environment for flash flood events at a snapshot or two in time in a numerical weather prediction model, this work emphasizes the importance of parcel residence times over source regions such as bodies of warm water, unidirectional or slightly veering low-level flow supportive of isentropic ascent, and favorable scenarios for flash flooding that vary by region and season. These findings may assist forecasters in predicting heavy rainfall and flash flooding several days in advance of the event.

The importance of considering the lifetime of the parcel prior to a flash flood event will be further explored in Part II of this manuscript, which utilizes the same computation of trajectories and a simulation of a land surface model to assess the land surface conditions and their anomalies at times when the specific humidity along each parcel's trajectory increases.

Acknowledgments. The first author has been partially supported for this work by the NSF Graduate Research Fellowship under Grant DGE-1102691. Partial funding for this research was provided by the Disaster Relief Appropriations Act of 2013 (P.L. 113-2), which provided support to the Cooperative Institute for Mesoscale Meteorological Studies at the University of Oklahoma (OU) under Grant NA14OAR4830100 and National Science Foundation Grant Award ICER1663840. Some of the computing for this project was performed at the OU Supercomputing Center for Education and $\mathrm{Re}$ search (OSCER) at OU.

\section{REFERENCES}

Adams, D. K., and A. C. Comrie, 1997: The North American Monsoon. Bull. Amer. Meteor. Soc., 78, 2197-2213, https:// doi.org/10.1175/1520-0477(1997)078<2197:TNAM>2.0.CO;2.

Ashley, S. T., and W. S. Ashley, 2008: Flood fatalities in the United States. J. Appl. Meteor. Climatol., 47, 805-818, https://doi.org/ 10.1175/2007JAMC1611.1.

Baker, V. R., 1975: Flood hazards along the balcones escarpment in central Texas: Alternative approaches to their recognition, mapping, and management. Geological Circular 75, 20 pp., http://legacy.lib.utexas.edu/books/landscapes/publications/txuoclc-1967634/txu-oclc-1967634.pdf.

Beck, J., and C. Weiss, 2013: An assessment of low-level baroclinity and vorticity within a simulated supercell. Mon. Wea. Rev. 141, 649-669, https://doi.org/10.1175/MWR-D-11-00115.1.

Brooks, H. E., and D. J. Stensrud, 2000: Climatology of heavy rain events in the United States from hourly precipitation observations. Mon. Wea. Rev., 128, 1194-1201, https://doi.org/10.1175/ 1520-0493(2000)128<1194:COHREI > 2.0.CO;2.

Caracena, F., R. A. Maddox, L. R. Hoxit, and C. F. Chappell, 1979: Mesoanalysis of the Big Thompson Storm. Mon. Wea. Rev., 107, 1-17, https://doi.org/10.1175/1520-0493(1979)107<0001: MOTBTS $>2.0 . \mathrm{CO} ; 2$.
Caran, S. C., and V. R. Baker, 1986: Flooding along the Balcones Escarpment, Central Texas. The Balcones Escarpment: Geology, Hydrology, Ecology and Social Development in Central Texas, P. L. Abbot and C. M. J. Woodruff, Eds., Geological Society of America, 1-14, http://legacy.lib.utexas.edu/geo/ balcones_escarpment/contents.html.

Carbone, R. E., and J. D. Tuttle, 2008: Rainfall occurrence in the U.S. warm season: The diurnal cycle. J. Climate, 21, 4132-4146, https://doi.org/10.1175/2008JCLI2275.1.

Cook, K. H., and E. K. Vizy, 2010: Hydrodynamics of the Caribbean low-level jet and its relationship to precipitation. J. Climate, 23, 1477-1494, https://doi.org/10.1175/2009JCLI3210.1.

DeAngelis, A., F. Dominguez, Y. Fan, A. Robock, M. D. Kustu, and D. Robinson, 2010: Evidence of enhanced precipitation due to irrigation over the Great Plains of the United States. J. Geophys. Res., 115, D15115, https://doi.org/10.1029/2010JD013892.

Dirmeyer, P. A., and J. L. Kinter, 2010: Floods over the U.S. Midwest: A regional water cycle perspective. J. Hydrometeor., 11, 1172-1181, https://doi.org/10.1175/2010JHM1196.1.

Dominguez, F., G. Miguez-Macho, and H. Hu, 2016: WRF with water vapor tracers: A study of moisture sources for the North American Monsoon. J. Hydrometeor., 17, 1915-1927, https:// doi.org/10.1175/JHM-D-15-0221.1.

Doswell, C. A., H. E. Brooks, and R. A. Maddox, 1996: Flash flood forecasting: An ingredients-based methodology. Wea. Forecasting, 11, 560-581, https://doi.org/10.1175/1520-0434(1996) $011<0560$ :FFFAIB $>2.0$. CO;2.

Erlingis, J. M., J. J. Gourley, and J. B. Basara, 2019: Diagnosing moisture sources for flash floods in the United States. Part II: Terrestrial and oceanic sources of moisture. J. Hydrometeor., 20, 1511-1531, https://doi.org/10.1175/JHM-D-18-0120.1.

Galewsky, J., A. Sobel, and I. Held, 2005: Diagnosis of subtropical humidity dynamics using tracers of last saturation. J. Atmos. Sci., 62, 3353-3367, https://doi.org/10.1175/JAS3533.1.

Gochis, D., and Coauthors, 2015: The great Colorado flood of September 2013. Bull. Amer. Meteor. Soc., 96, 1461-1487, https://doi.org/10.1175/BAMS-D-13-00241.1.

Gourley, J. J., J. M. Erlingis, T. M. Smith, K. L. Ortega, and Y. Hong, 2010: Remote collection and analysis of witness reports on flash floods. J. Hydrol., 394, 53-62, https://doi.org/ 10.1016/j.jhydrol.2010.05.042.

—, and Coauthors, 2013: A unified flash flood database across the United States. Bull. Amer. Meteor. Soc., 94, 799-805, https:// doi.org/10.1175/BAMS-D-12-00198.1.

Groisman, P. Ya., R. W. Knight, and T. R. Karl, 2012: Changes in intense precipitation over the central United States. J. Hydrometeor., 13, 47-66, https://doi.org/10.1175/JHM-D-11-039.1.

Hardy, J., J. J. Gourley, P. E. Kirstetter, Y. Hong, F. Kong, and Z. L. Flamig, 2016: A method for probabilistic flash flood forecasting. J. Hydrol., 541, 480-494, https://doi.org/10.1016/ j.jhydrol.2016.04.007.

Hardy, S., D. M. Schultz, and G. Vaughan, 2017: Early evolution of the 23-26 September 2012 U.K. floods: Tropical Storm Nadine and diabatic heating due to cloud microphysics. Mon. Wea. Rev., 145, 543-563, https://doi.org/10.1175/MWR-D-16-0200.1.

Hicks, N. S., J. A. Smith, A. J. Miller, and P. A. Nelson, 2005: Catastrophic flooding from an orographic thunderstorm in the central Appalachians. Water Resour. Res., 41, W12428, https:// doi.org/10.1029/2005WR004129.

Higgins, R. W., Y. Yao, and X. L. Wang, 1997: Influence of the North American monsoon system on the U.S. summer precipitation regime. J. Climate, 10, 2600-2622, https://doi.org/ 10.1175/1520-0442(1997)010<2600:IOTNAM>2.0.CO;2. 
Hirschboeck, K. K., 1991: Climate and floods. National water summary 1988-89: Hydrologic events and floods and droughts, USGS Water Supply Paper 2375, 67-88, https://pubs.er.usgs.gov/ publication/wsp2375.

Jana, S., B. Rajagopalan, M. A. Alexander, and A. J. Ray, 2018: Understanding the dominant sources and tracks of moisture for summer rainfall in the southwest United States. J. Geophys. Res. Atmos., 123, 4850-4870, https://doi.org/ 10.1029/2017JD027652.

Karl, T. R., and R. W. Knight, 1998: Secular trends of precipitation amount, frequency, and intensity in the United States. Bull. Amer. Meteor. Soc., 79, 231-241, https://doi.org/10.1175/15200477(1998)079<0231:STOPAF $>2.0 . C O ; 2$.

Kharin, V. V., F. W. Zwiers, X. Zhang, and M. Wehner, 2013: Changes in temperature and precipitation extremes in the CMIP5 ensemble. Climatic Change, 119, 345-357, https:// doi.org/10.1007/s10584-013-0705-8.

Kustu, M. D., Y. Fan, and M. Rodell, 2011: Possible link between irrigation in the U.S. High Plains and increased summer streamflow in the Midwest. Water Resour. Res., 47, W03522, https://doi.org/10.1029/2010WR010046.

Lavers, D. A., and G. Villarini, 2013: Atmospheric rivers and flooding over the central United States. J. Climate, 26, 7829-7836, https:// doi.org/10.1175/JCLI-D-13-00212.1.

Li, L., R. W. Schmitt, C. C. Ummenhofer, and K. B. Karnauskas, 2016: Implications of North Atlantic sea surface salinity for summer precipitation over the U.S. Midwest: Mechanisms and predictive value. J. Climate, 29, 3143-3159, https://doi.org/ 10.1175/JCLI-D-15-0520.1.

Maddox, R. A., L. R. Hoxit, C. F. Chappell, and F. Caracena, 1978: Comparison of meteorological aspects of the Big Thompson and Rapid City flash floods. Mon. Wea. Rev., 106, 375-389, https://doi.org/10.1175/1520-0493(1978)106<0375: COMAOT $>2.0 . \mathrm{CO} ; 2$.

- C. F. Chappell, and L. R. Hoxit, 1979: Synoptic and meso- $\alpha$ scale aspects of flash flood events. Bull. Amer. Meteor. Soc., 60, 115-123, https://doi.org/10.1175/1520-0477-60.2.115.

— D. M. McCollum, and K. W. Howard, 1995: Large-scale patterns associated with severe summertime thunderstorms over central Arizona. Wea. Forecasting, 10, 763-778, https://doi.org/ 10.1175/1520-0434(1995)010<0763:LSPAWS > 2.0.CO;2.

Mesinger, F., and Coauthors, 2006: North American Regional Reanalysis. Bull. Amer. Meteor. Soc., 87, 343-360, https:// doi.org/10.1175/BAMS-87-3-343.

Mitchell, D. L., D. Ivanova, and N. Severe, 2002: Gulf of California sea surface temperatures and the North American Monsoon : Mechanistic implications from observations. J. Climate, 15, 2261-2281, https://doi.org/10.1175/1520-0442(2002)015<2261: GOCSST $>2.0 . \mathrm{CO} ; 2$.

Mo, K. C., J. N. Paegle, and R. W. Higgins, 1997: Atmospheric processes associated with summer floods and droughts in the central United States. J. Climate, 10, 3028-3046, https://doi.org/ 10.1175/1520-0442(1997)010<3028:APAWSF>2.0.CO;2.

NCEP, 2005: NCEP North American Regional Reanalysis (NARR) (updated monthly). Research Data Archive at the National Center for Atmospheric Research, Computational and Information Systems Laboratory, accessed 26 July 2016, http://rda.ucar.edu/datasets/ds608.0/.

NSSL, 2013: U.S. Flash Flood Observation Database. Accessed 4 August 2016, https://blog.nssl.noaa.gov/flash/database/.

Neiman, P. J., F. M. Ralph, G. a. Wick, J. D. Lundquist, and M. D. Dettinger, 2008: Meteorological characteristics and overland precipitation impacts of atmospheric rivers affecting the west coast of North America based on eight years of SSM/I satellite observations. J. Hydrometeor., 9, 22-47, https://doi.org/ 10.1175/2007JHM855.1.

Nielsen, E. R., R. S. Schumacher, and A. M. Keclik, 2016: The effect of the Balcones Escarpment on three cases of extreme precipitation in central Texas. Mon. Wea. Rev., 144, 119-138, https://doi.org/10.1175/MWR-D-15-0156.1.

Ogden, F. L., H. O. Sharif, S. U. S. Senarath, J. A. Smith, M. L. Baeck, and J. R. Richardson, 2000: Hydrologic analysis of the Fort Collins, Colorado, flash flood of 1997. J. Hydrol., 228, 82-100, https://doi.org/10.1016/S0022-1694(00)00146-3.

Petersen, W. A., and Coauthors, 1999: Mesoscale and radar observations of the Fort Collins flash flood of 28 July 1997. Bull. Amer. Meteor. Soc., 80, 191-216, https://doi.org/10.1175/15200477(1999)080<0191:MAROOT>2.0.CO;2.

Prein, A. F., R. M. Rasmussen, K. Ikeda, C. Liu, M. P. Clark, and G. J. Holland, 2017: The future intensification of hourly precipitation extremes. Nat. Climate Change, 7, 48-52, https:// doi.org/10.1038/nclimate3168.

Ralph, F. M., P. J. Neiman, and G. A. Wick, 2004: Satellite and CALJET aircraft observations of atmospheric rivers over the eastern North Pacific Ocean during the winter of 1997/98. Mon. Wea. Rev., 132, 1721-1745, https://doi.org/10.1175/15200493(2004)132<1721:SACAOO>2.0.CO;2.

,,,-- S. I. Gutman, M. D. Dettinger, D. R. Cayan, and A. B. White, 2006: Flooding on California's Russian River: Role of atmospheric rivers. Geophys. Res. Lett., 33, L13801, https://doi.org/10.1029/2006GL026689.

Roberts, N. M., S. J. Cole, R. M. Forbes, R. J. Moore, and D. Boswellc, 2009: Use of high-resolution NWP rainfall and river flow forecasts for advance warning of the Carlisle flood, north-west England. Meteor. Appl., 16, 23-34, https://doi.org/ 10.1002/met.94.

Saharia, M., P. Kirstetter, H. Vergara, J. J. Gourley, Y. Hong, and M. Giroud, 2017: Mapping flash flood severity in the United States. J. Hydrometeor., 18, 397-411, https://doi.org/10.1175/ JHM-D-16-0082.1.

Schroeder, A. J., and Coauthors, 2016: The development of a flash flood severity index. J. Hydrol., 541, 523-532, https://doi.org/ 10.1016/j.jhydrol.2016.04.005.

Schumacher, R. S., and R. H. Johnson, 2005: Organization and environmental properties of extreme-rain-producing mesoscale convective systems. Mon. Wea. Rev., 133, 961-976, https://doi.org/10.1175/MWR2899.1.

— , and - 2006: Characteristics of U.S. extreme rain events during 1999-2003. Wea. Forecasting, 21, 69-85, https://doi.org/ 10.1175/WAF900.1.

Slater, T. P., D. M. Schultz, and G. Vaughan, 2015: Acceleration of near-surface strong winds in a dry, idealised extratropical cyclone. Quart. J. Roy. Meteor. Soc., 141, 1004-1016, https:// doi.org/10.1002/qj.2417.

Smart, D. J., and K. A. Browning, 2014: Attribution of strong winds to a cold conveyor belt and sting jet. Quart. J. Roy. Meteor. Soc., 140, 595-610, https://doi.org/10.1002/qj.2162.

Smith, B. K., and J. A. Smith, 2015: The flashiest watersheds in the contiguous United States. J. Hydrometeor., 16, 2365-2381, https://doi.org/10.1175/JHM-D-14-0217.1.

Smith, B. L., S. E. Yuter, P. J. Neiman, and D. E. Kingsmill, 2010: Water vapor fluxes and orographic precipitation over Northern California associated with a landfalling atmospheric river. Mon. Wea. Rev., 138, 74-100, https://doi.org/10.1175/2009MWR2939.1.

Smith, J. A., M. L. Baeck, A. A. Ntelekos, G. Villarini, and M. Steiner, 2011: Extreme rainfall and flooding from orographic 
thunderstorms in the central Appalachians. Water Resour. Res., 47, 1-24, https://doi.org/10.1029/2010WR010190.

Stensrud, D. J., R. L. Gall, S. L. Mullen, and K. W. Howard, 1995: Model climatology of the Mexican monsoon. J. Climate, $\mathbf{8}$, 1775-1794, https://doi.org/10.1175/1520-0442(1995)008<1775: MCOTMM $>2.0 . \mathrm{CO} ; 2$.

Stoelinga, M. L., 2009: A users' guide to RIP version 4.5: A program for visualizing mesoscale model output. Accessed 01 July 2014, http://www2.mmm.ucar.edu/wrf/users/docs/ripug.htm.

Sturdevant-Rees, P., J. A. Smith, J. Morrison, and M. L. Baeck, 2001: Tropical storms and the flood hydrology of the central Appalachians. Water Resour. Res., 37, 2143-2168, https:// doi.org/10.1029/2000WR900310.

Tao, J., and A. P. Barros, 2013: Prospects for flash flood forecasting in mountainous regions - An investigation of Tropical Storm Fay in the Southern Appalachians. J. Hydrol., 506, 69-89, https://doi.org/10.1016/j.jhydrol.2013.02.052.

Tilev-Tanriover, S., and A. Kahraman, 2015: Saharan dust transport by Mediterranean cyclones causing mud rain in Istanbul. Weather, 70, 145-145, https://doi.org/10.1002/ wea. 2472 .

Villarini, G., and J. A. Smith, 2010: Flood peak distributions for the eastern United States. Water Resour. Res., 46, 1-17, https:// doi.org/10.1029/2009WR008395.

—_, R. Goska, J. A. Smith, and G. A. Vecchi, 2014: North Atlantic tropical cyclones and U.S. flooding. Bull. Amer. Meteor. Soc., 95, 1381-1388, https://doi.org/10.1175/BAMSD-13-00060.1.

Vincendon, B., V. Ducrocq, O. Nuissier, and B. Vié, 2011: Perturbation of convection-permitting NWP forecasts for flash-flood ensemble forecasting. Nat. Hazards Earth Syst. Sci., 11, 1529-1544, https://doi.org/10.5194/nhess-11-1529-2011.

Wang, N., X. Zeng, Y. Zheng, J. Zhu, and S. Jiang, 2018: The atmospheric moisture residence time and reference time for moisture tracking over China. J. Hydrometeor., 19, 1131-1147, https://doi.org/10.1175/JHM-D-17-0204.1.

Wang, S. Y., and T. C. Chen, 2009: The late-spring maximum of rainfall over the U.S. Central Plains and the role of the lowlevel jet. J. Climate, 22, 4696-4709, https://doi.org/10.1175/ 2009JCLI2719.1.

Wernli, H., M. Paulat, M. Hagen, and C. Frei, 2008: SAL-A novel quality measure for the verification of quantitative precipitation forecasts. Mon. Wea. Rev., 136, 4470-4487, https:// doi.org/10.1175/2008MWR2415.1.

Wooten, R. M., K. A. Gillon, A. C. Witt, R. S. Latham, T. J. Douglas, J. B. Bauer, S. J. Fuemmeler, and L. G. Lee, 2008: Geologic, geomorphic, and meteorological aspects of debris flows triggered by Hurricanes Frances and Ivan during September 2004 in the Southern Appalachian Mountains of Macon County, North Carolina (southeastern USA). Landslides, 5, 31-44, https://doi.org/10.1007/ s10346-007-0109-9.

Wuebbles, D., and Coauthors, 2014: CMIP5 climate model analyses: Climate extremes in the United States. Bull. Amer. Meteor. Soc., 95, 571-583, https://doi.org/10.1175/BAMS-D12-00172.1.

Zhu, Y., and R. E. Newell, 1998: A proposed algorithm for moisture fluxes from atmospheric rivers. Mon. Wea. Rev., 126, 725-735, https://doi.org/10.1175/1520-0493(1998)126<0725: APAFMF $>2.0 . \mathrm{CO} ; 2$. 